\title{
Analysis of Energy Use in Building Services of the Industrial Sector in California: Two Case Studies
}

September 1991

\author{
Final Report \\ Hashem Akbari and Osman Sezgen \\ Energy Analysis Program \\ Energy and Environment Division \\ Lawrence Berkeley Laboratory \\ University of California \\ Berkeley, CA 94720
}

This study was sponsored by the California Institute for Energy Efficiency (CIEE) (Award No. EXP-90-09) through the U.S. Department of Energy under Contract No. DE-AC03-76SF00098. 


\title{
Analysis of Energy Use in Building Services of the Industrial Sector in California: Two Case Studies
}

\author{
Hashem Akbari and Osman Sezgen
}

\begin{abstract}
Energy-use patterns in many of California's fastest-growing industries are not typical of the existing mix of industries elsewhere in the U.S. Many California firms operate small- and medium-sized facilities housed in buildings used simultaneously or interchangeably over time for commercial (office, retail, warehouse) and industrial activities. In these industrial subsectors, the energy required for building services (providing occupant comfort and necessities like lighting, HVAC, office equipment, computers, etc.) may be at least as important as the more familiar process energy requirements-especially for electricity and on-peak demand. Electricity for building services is sometimes priced as if it were base loaded like process uses; in reality this load varies significantly according to occupancy schedules and cooling and heating loads, much as in any commercial building.

Using informal field surveys, simulation studies, and detailed analyses of existing data (including utility commercial/industrial audit files), we studied the energy use of this industrial subsector through a multi-step procedure: (1) characterizing non-process building energy and power use in California industries, (2) identifying conservation and load-shaping opportunities in industrial building services, and (3) investigating industrial buildings and system design methodologies. In an earlier report, we addressed these issues by performing an extensive survey of the existing publicly available data, characterizing and comparing the building energy use in this sector. In this report, we address the above objectives by examining and analyzing energy use in two industrial case-study facilities in California. Based on the information for the case studies, we discuss the design consideration for these industrial buildings, characterize their energy use, and review their conservation and load-shaping potentials. In addition, we identify and discuss some research ideas for further investigation.

This study concludes that the lighting and HVAC energy-use characteristics of high-tech industries (as represented by our case-study buildings) and their conservation potentials are comparable to those of office buildings. Simulating the impact of conservation measures commonly recommended for office buildings, we estimate that more than $50 \%$ of electricity and gas use for the building services in the two case-study facilities can be saved. Case studies in other regions and for other important industries can provide useful information to better understand the energy-use patterns and the impact of conservation and load-shaping measures on the industrial loads.
\end{abstract}




\section{ACKNOWLEDGEMENT}

The research reported here was funded by the California Institute for Energy Efficiency (CIEE), a research unit of the University of California. Publication of research results does not imply CIEE endorsement of or agreement with these findings, nor that of any CIEE sponsor.

We are indebted to Ms. Pamela Tuft and Mr. Rob Burkhart of City of San Jose; and Mark Barkdul of Kinco, Inc. for their assistance in selection of the case-study sites. We are also indebted to Mr. Bernard Orovitz and Mr. Joseph Huysentruyt of South Bay Circuits, Inc.; and Mr. Danny Cheadle Jr. of Cougar Components, Inc. for participating in this study. 


\section{Table of Contents}

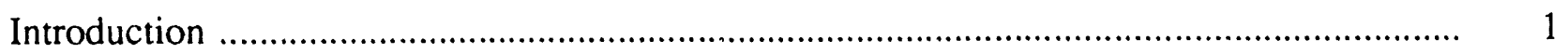

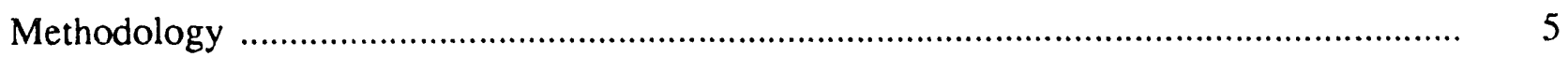

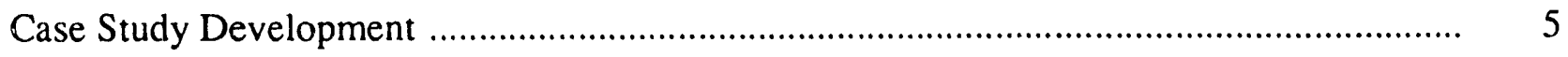

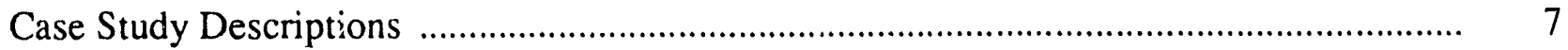

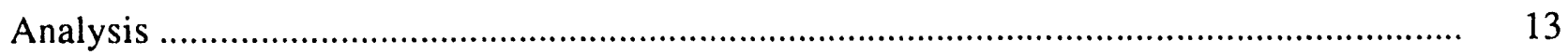

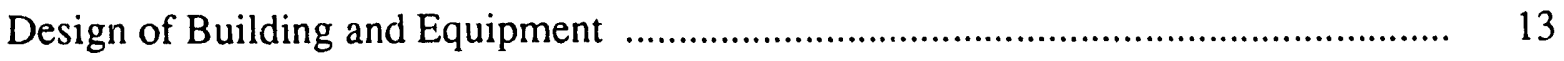

Energy Use Patterns and Characteristics ......................................................... 16

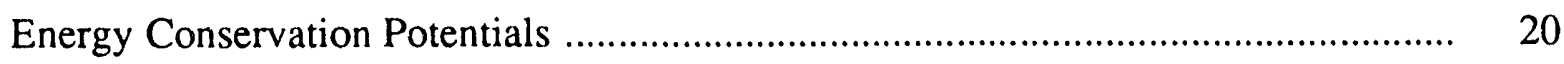

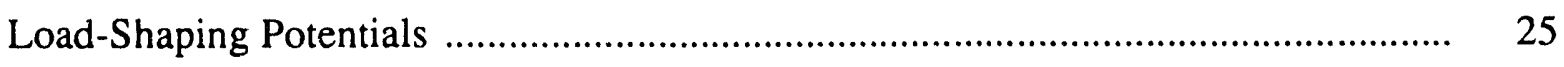

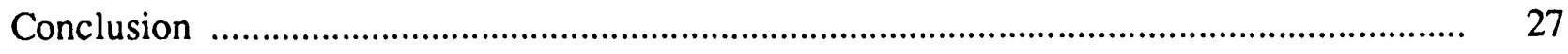

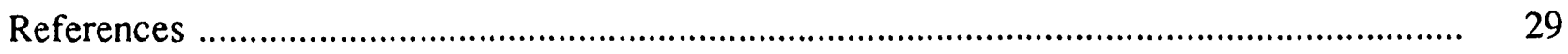




\title{
Analysis of Energy Use in Building Services of the Industrial Sector in California:
}

\author{
Two Case Studies
}

\section{INTRODUCTION}

California has a large number of small- and medium-sized industrial plants. These industries have a major impact on the growth rate of the electric utilities. ${ }^{1}$ Energy use for building services (lighting, HVAC, office equipment, computers, etc.) constitutes an important fraction of the total site energy use. This fraction is determined by the industrial activity, the size, and the climatological location of the facility. Also, energy use in building services is more responsive to weather and occupant schedules than the traditional base-load industrial process energy.

Presently, the energy use for building services in the industrial sector is not often distinguished from process load by utility companies. Data on non-process energy use are not readily available in the literature. Process energy use is considered a hase load by utility companies because it tends to increase the utilities' load factor. To increase their load factor further, utilities sometimes market energy at lower rates to industrial facilities. In those cases where energy is used primarily for building services, which have daily (and seasonal) load profiles that tend to peak at the same time as the system, the utility may be selling peak power below cost.

The industrial sector consumes approximately one-third of the energy used in California. Compared to the building services (non-process) loads, energy consumption for industrial processes has been far better researched and documented (ANCO 1986, Bodine 1980, Brown 1985, Chem Systems 1986, Chiogioji 1979, Fazzolare 1981, Hu 1983, IETEC 1984, Meckler 1984, Miller 1982, Reay 1979, and Smith 1978). Moreover, the availability of measured data on energy-use applications within industrial buildings is limited. Furthermore, the limited data that

\footnotetext{
1 In Northern and Central California, PG\&E identified Food and Related Pioducts (SIC 20), Computing Equipment and Electronics (SIC 35,36) having significant growth in the next 20 years. Together these industries represented about 40 percent of the region's industrial electricity sales in 1984 (PG\&E 1985).
} 
are available to estimate energy use for building services in industrial facilities are conflicting.

In our earlier report, we presented the results of a limited initial literature review on energy-use characteristics of the building services in the industrial sector in California (Akbari $e t$ al. 1991). Our data sources were limited to a computer survey (RECON), ASHRAE awardwinners (20 buildings), an initial review of the 1979 Non-Residential Building Energy Consumption Survey (NBECS-79), reports from Energy Analysis and Diagnostic Centers (EADC), and reports prepared for utilities, DOE, and other state and federal governmental institutions. In addition to the general literature, there were few other sources of data specific to California.

The Pacific Gas and Electric Company (PG\&E) has conducted industrial audits under its energy conservation program. The audits included detailed information on the process and nonprocess electrical loads of these facilities. An initial review of a few of these audits provided us with some useful information on the non-process energy use of these facilities (Akbari et al. 1991). There are also some indications that such data might be available from the Southern California Edison Company (SCE). In addition to these two main California utilities, the California Energy Commission (CEC) has funded a study to review the energy-use characteristics of California manufacturing industries (Miller 1982). Table 1 (after Akbari et al. 191) summarizes the data sources. Our analysis of these data reveals that further clarification and characterization of energy end-use is necessary to determine conservation potentials of the building service category.

One estimate of energy use indicates that, nationwide, about $100 \mathrm{TWh}$ (13.5\% of industrial electricity) is consumed by the building services of the industrial sector (Smith 1978). There are indications that this figure may not include all power used for HVAC fans, pumps, and compressors. This percentage is undoubtedly higher in newer (light) industries with high occupancy levels or special needs for environmental conditioning - as is the case for many California industries. Thus, the industrial building services represent an even larger portion of electricity use (and peak demand) in California industries. Our study has also indicated a shift toward the use of electricity and away from fuel at the facility site. With lower and nearly stablized fuel (i.e., gas, oil, and coal) prices, the rate of this effect is expected to decrease. If the price of electricity continues to increase relative to fuel, more site fuel use could be expected in cogeneration applications where air quality and other factors permit. 


\begin{tabular}{|c|c|c|c|c|c|c|}
\hline 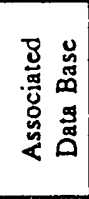 & & 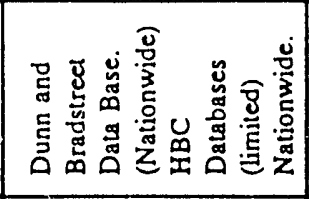 & & 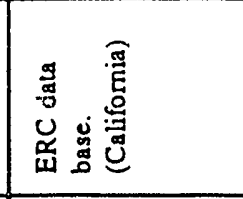 & 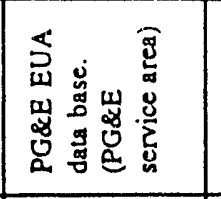 & 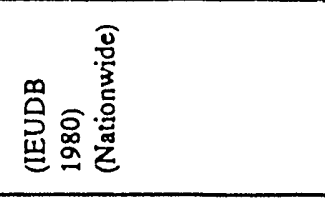 \\
\hline 离 & 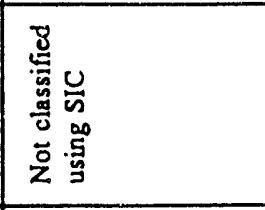 & 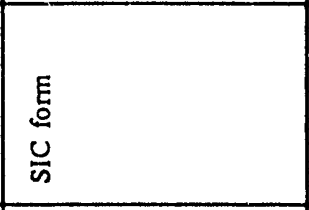 & $\begin{array}{l}\frac{E}{\mathrm{~g}} \\
\frac{\mathrm{U}}{5}\end{array}$ & 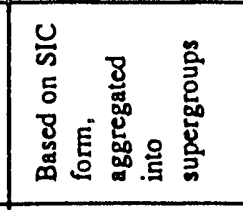 & 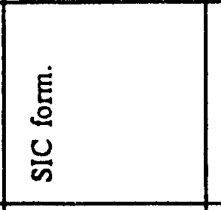 & $\begin{array}{l}\frac{E}{0} \\
\frac{O}{0} \\
\end{array}$ \\
\hline 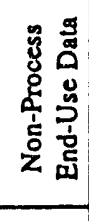 & 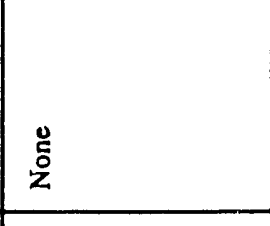 & 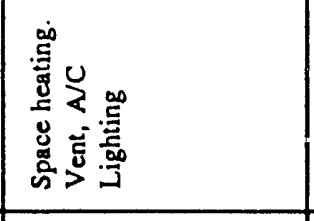 & $\begin{array}{l}\stackrel{0}{\circ} \\
\stackrel{\circ}{2} \\
\end{array}$ & 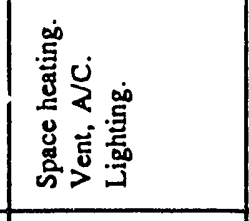 & 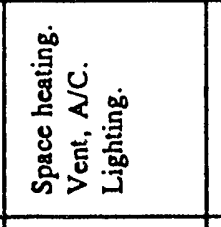 & 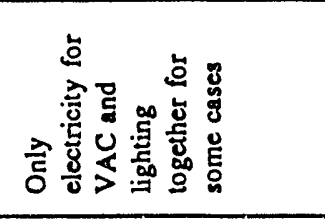 \\
\hline 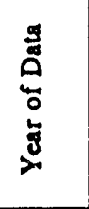 & $\stackrel{\circ}{g}$ & 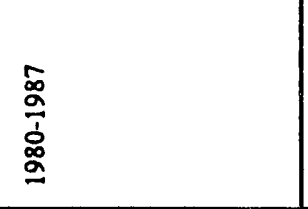 & 鵕 & $\begin{array}{l}5 \\
\text { 章 } \\
\frac{\bar{z}}{2} \\
\end{array}$ & 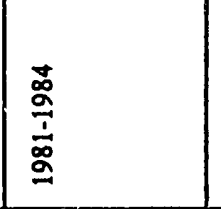 & 器 \\
\hline 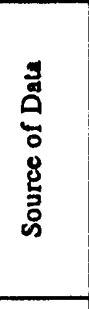 & 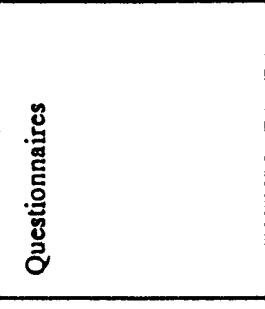 & 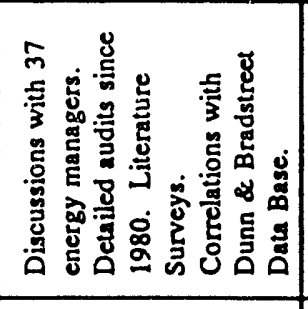 & 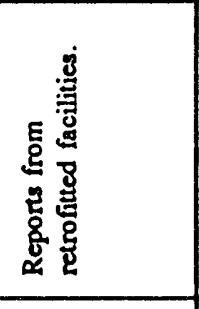 & 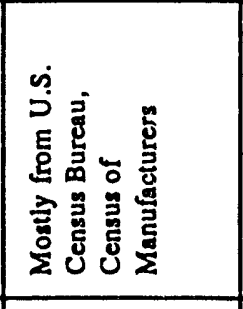 & 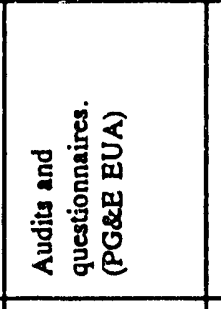 & 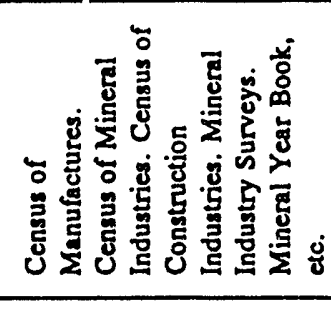 \\
\hline 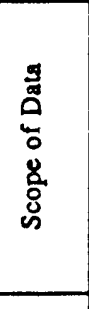 & 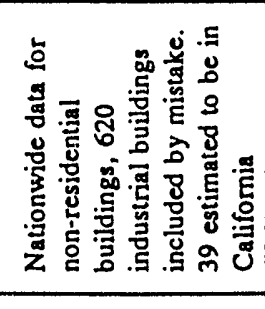 & 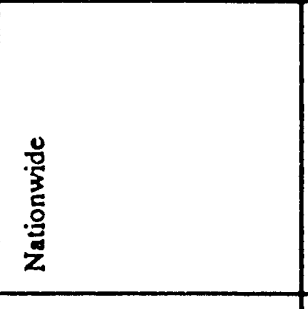 & 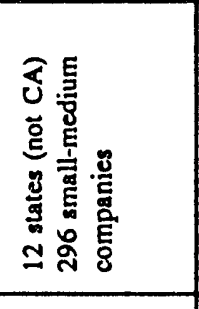 & 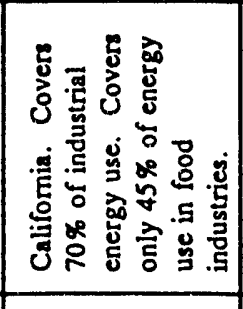 & 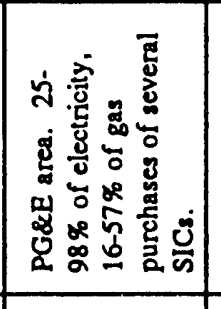 & 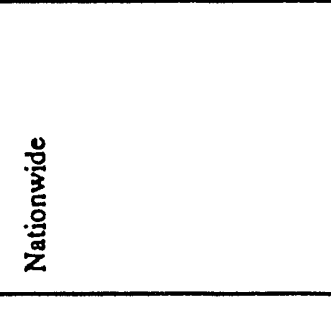 \\
\hline 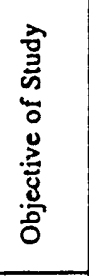 & 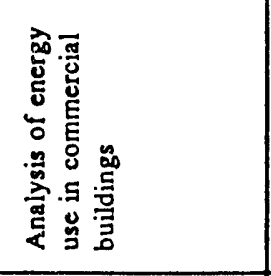 & 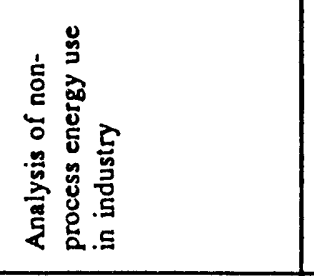 & 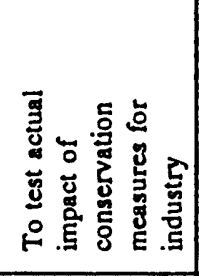 & 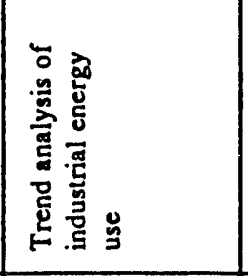 & 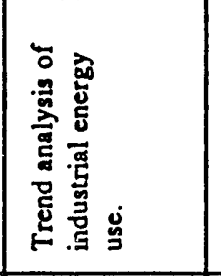 & 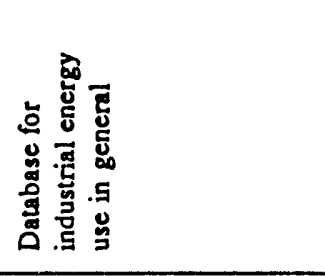 \\
\hline 吾 & 㟒 & 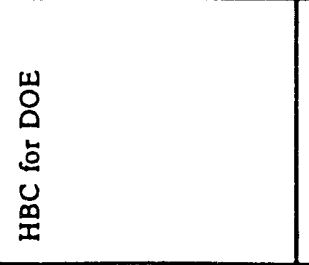 & 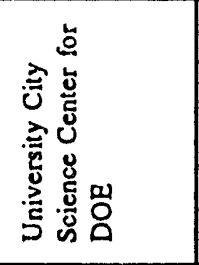 & 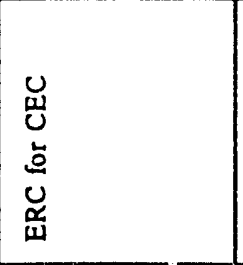 & 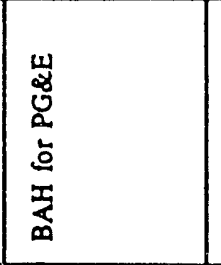 & 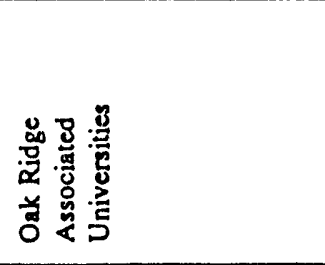 \\
\hline 意 & 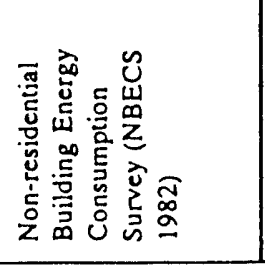 & 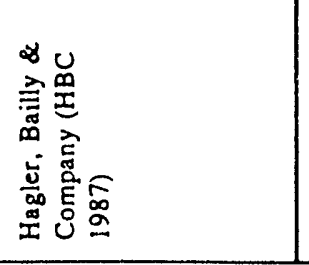 & 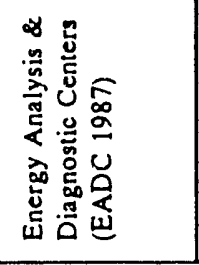 & 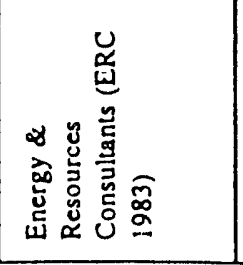 & 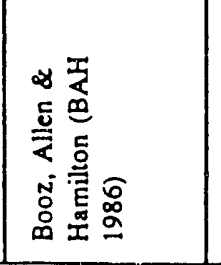 & 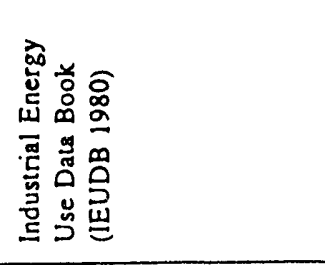 \\
\hline
\end{tabular}


We have found that industrial buildings are not necessarily as distinct from other types of non-residential buildings as is commonly thought. For practical reasons, many light industrial buildings are often physically similar to retail or office structures (see the case-study section). Where occupants are in an enclosed space, they need to be provided comfort conditioning and lighting levels comparable to commercial buildings. California industrial buildings almost always contain some office workers; and the same structure, over its lifetime, may shift between industrial and non-industrial uses. Compared to other non-residential buildings, industrial buildings may have higher thermal loads, air-change rates, longer operating hours, and greater pollution-control or other environmental-conditioning requirements.

In this study, we analyze building energy use in two selected facilities as case studies. The selected facilities, to the extent possible, were chosen from those that already have been audited (either by PG\&E or others). The specific goals of this study were to determine:

a) How are industrial buildings and systems designed?

b) What are their energy-use characteristics?

c) What are their conservation and load-shaping potentials?

Our methodology consisted of collecting historical buildings characteristics data, on-site visits and interviews with building operators and managers, and follow-up analysis of collected data using the DOE-2 building energy simulation model.

In the following sections, we discuss the methodology in further detail, provide a summary of case-study facilities, analyze building and equipment design methodology, analyze energyuse patterns and characteristics, and review potentials in conservation and load-shaping opportunities. We conclude the report by discussing future research needs in this area.

1 To study some of the issues posed above, the University-wide Energy Research Group (UERG) of the University of California and the Lawrence Berkeley Laboratory jointly sponsored a one-day workshop in November 1988, with invited participation from researchers, California Energy Commission, and California utilities (Akbari and Gadgil 1989). The workshop focused on energy use in industrial buildings, summarized the existing knowledge in the field, and identified gaps in data for energy and peak forecasting, as well as for analysis of load-shaping and conservation strategies. The three key issues discussed were data needs, data availability, and gaps in existing knowledge. The workshop highlighted the need to improve our understanding of this neglected sector of energy use. 


\section{METHODOLOGY}

Based on the findings of Akbari et al. (1991), five industries (electronics, instrumentation, food processing, meat packing, and automotive industries) were chosen as case studies. The methodology consisted of case-study development, information gathering, and information analysis phases.

For case-study development, we contacted several industrial building owners, utilities, and municipal offices in an effort to identify facilities that might be studied. Once a facility was identified, we

- interviewed the owners to ascertain the design procedure for building the facilities and installing the equipment;

- $\quad$ acquired the building and systems as-built drawings;

- obtained the owners' help in contacting the tenants who were occupying the huilding;

- contacted the tenants and convinced them to participate in the study;

- interviewed the tenants to find out about the details of their operations and their schedules;

- $\quad$ acquired their utility bills for one year;

- obtained information on how the facility and the associated HVAC equipment had to be modified or extended to suit their operation; and

- $\quad$ performed an on-site survey of the building and equipment in the facility.

Our analysis of the collected information addressed three objectives, the identification of (1) building and equipment design characteristics, (2) energy-use patterns, and (3) conservation and load-shaping opportunities. In the analysis of conservation and load-shaping potentials, we relied on computer simulation, using the DOE-2 building energy analysis program.

\section{CASE-STUDY DEVELOPMENT}

Case Study 1: Approximately 30 industrial park developers and owners in the San Francisco Bay Area were contacted. Unfortunately, there was little interest by the owners in participating in this project; only one owner reluctantly agreed to be interviewed. This developer owned several industrial parks occupied by a variety of tenants in the Santa Clara area. During our interview with the owner, we discussed his approach in the design and construction of the buildings, the lighting systems, and the HVAC systems for the industrial parks. With the owner's assistance, we prepared a list of tenants who might be interested in developing case 
studies of their facilities. The candidates were primarily involved in manufacturing or assembling electronic components.

Fifteen of these candidates were contacted, but only one company (involved in manufacturing microwave components) responded positively. Once the site was selected, we visited the building owner for a second time and obtained building details by reviewing with him the asbuilt drawings. Later, we visited the facility for a detailed interview with the tenant, examined the building, and obtained the utility bills. After some initial analysis of the collected data and DOE-2 modeling of the building, we revisited the building in an effort to reconcile the differences between the utility bills and our simulation results.

Case Study 2: While developing the first case study, we discovered that the City of San Jose had contracted a private company to perform energy audits for 50 facilities that used significant amounts of energy and water. At our request, the City provided us with a copy of one of the completed audit reports and also promised to send copies of the other audits as they became available.

We successfully contacted the audited facility and requested their participation in our project as a second case study. We thoroughly interviewed one of the vice presidents of the company and the facility's manager. As a result of this effort, missing data from the audit were filled in. More importantly, this case study provided us with a chance to understand the dynamics of how HVAC and building service equipment are designed and installed, and how the systems change when tenants change.

This facility was involved in manufacturing printed circuit boards. The facility occupied four buildings, twe of which were used for manufacturing. These buildings were typical of the industrial park developments in the San Jose and Santa Clara areas. The two buildings were similar in nature and operated independently of each other; therefore, only one of them was inspected during our visil. The same building was visited later for a more detailed study of the process equipment and its interaction with the building systems and envelope.

We modeled the energy use of the facility, using the DOE-2 program, in an effort to identify conservation potentials. Since distinctive processes took place in different sections of the facility, matching the DOE-2 simulation results to the actual utility bills was difficult. One major reason for this difficulty was that energy used by some process equipment did not affect the building HVAC system. An example was the use of dedicated chilled water loops for direct 
cooling of some of the process equipment. Because of such complications, we relied on surface temperature measurements to estimate the internal gains caused by process equipment.

\section{CASE-STUDY DESCRIPTIONS}

Both case-study facilities are housed in similar buildings that are typical of industrial park buildings in California. These facilities are used both for office and industrial activities with significant process loads. The two cases represent both ends of this spectrum. Case Study 1 is a manufacturer of small instruments whose schedules and space-use characteristics are very similar to those of an office building. In this facility, most process equipment was used intermittently. The equipment that was used continuously (e.g., microscopes and electronic test equipment) had similar energy-use characteristics as office equipment (personal computers, etc.). On the other hand, Case Study 2, a printed circuit board manufacturer, used process equipment that was operated continuously.

Figures 1 and 2 show the general layout of these buildings. To audit these buildings, we used the PG\&E's Commercial On-Site Questionnaire. The audit information is summarized in Table 2. Envelope characteristics were obtained from as-built drawings and verified and updated by observations. Information on lighting characteristics was gathered by counting fixtures. Data on HVAC equipment were collected by reading the nameplate information on the equipment. Information on HVAC equipment control and schedules was obtained from the facilities' managers. During our visits to the facilities and through the interviews, we also obtained fairly accurate data on occupancy, lighting equipment, kitchen equipment, and operating schedules.

There were two sources of complication in quantifying internal heat gains to the conditioned space by the process equipment. First, the operational schedules related to the equipment were very complex. It was difficult to determine what percentage of the rated power was being consumed at a given timc. Second, energy used by the equipment was often removed from the system by either exhaust fans or dedicated chilled water loops before it could affect the building's space-conditioning load. In such a situation, we relied on our own surface temperature measurements to estimate internal heat gains for each piece of equipment. Common examples of such equipment were ovens with exhaust fans and hot processes with a local chilled water loop. 
Figure 1.

Floor Plan of the Microwave Component Manufacturing Facility (Case Study 1)

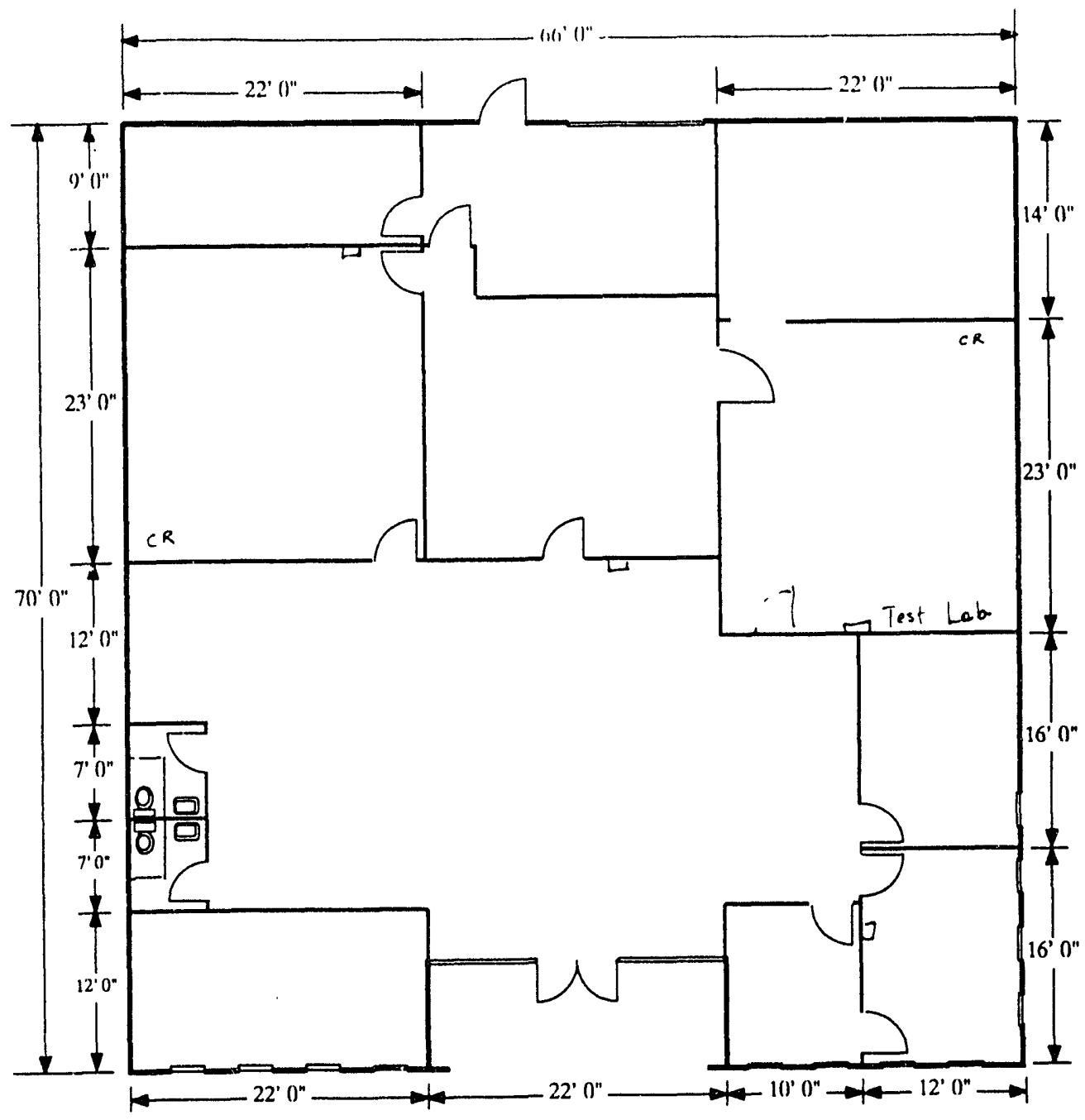


Figure 2.

Floor Plan of the Printed Circuit Board Manufacturing Facility (Case Study 2)

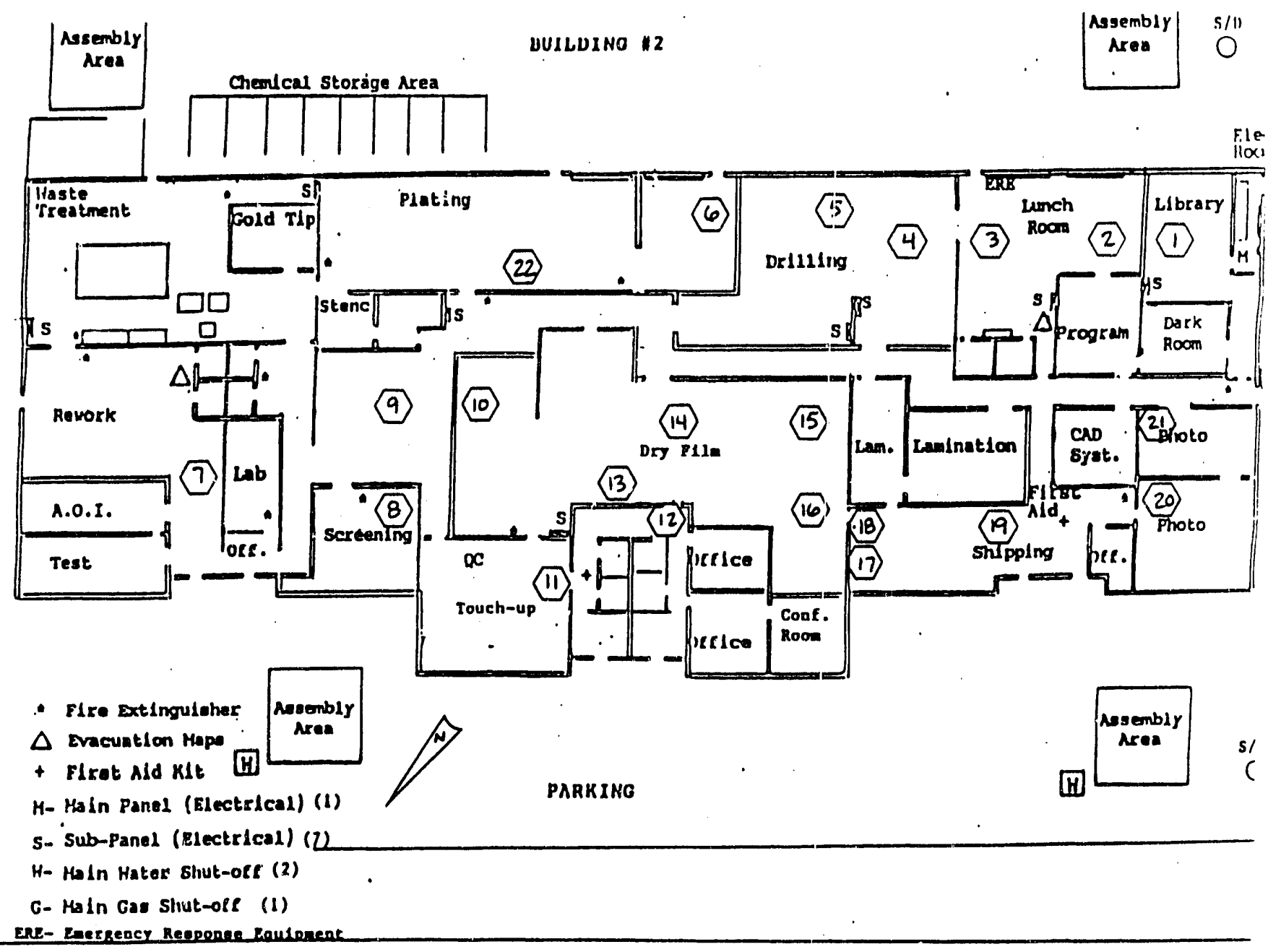


Table 2. Case Study Building and System Characteristics

\begin{tabular}{|c|c|c|c|}
\hline \multicolumn{2}{|c|}{ Characteristic } & Case I & Case II \\
\hline \multicolumn{2}{|l|}{ Function } & $\begin{array}{l}\text { Manufacturing of microwave } \\
\text { component. }\end{array}$ & $\begin{array}{l}\text { Manufacturing of printed } \\
\text { circuit boards. }\end{array}$ \\
\hline \multicolumn{2}{|c|}{ Size \& Layout } & $\begin{array}{l}1 / \mathrm{s} \text { of a } 15,000 \mathrm{ft}^{2} \text { single story } \\
\text { building. }\end{array}$ & $\begin{array}{l}26,000 \mathrm{ft}^{2} \text { building, single } \\
\text { story. }\end{array}$ \\
\hline \multirow[t]{6}{*}{ ENVELOPE } & Walls & $\begin{array}{l}6^{n} \text { concrete tilt-up walls, no } \\
\text { wall insulation. }\end{array}$ & $\begin{array}{l}6^{\prime \prime} \text { concrete tilt-up walls, no } \\
\text { wall insulation. }\end{array}$ \\
\hline & $\begin{array}{l}\text { Interior } \\
\text { Walls }\end{array}$ & $\begin{array}{l}3 \% \%^{\prime \prime} \text { metal studs \& } 1 / 2 " \\
\text { gypboard both sides. }\end{array}$ & $\begin{array}{l}3 \% / \% " \text { metal studs \& } 1 / 2 " \\
\text { gypboard hoth sides. }\end{array}$ \\
\hline & Roof & $\begin{array}{l}\text { Built-ip roofing over } 1 / 2 " \\
\text { plywood deck. } \\
\text { Roof height } 16^{\prime} \text {. }\end{array}$ & $\begin{array}{l}\text { Built-up roofing over ' } 1 \text { " } \\
\text { plywood deck. } \\
\text { Roof height } 13 \text { '. }\end{array}$ \\
\hline & Ceilings & $\begin{array}{l}\text { Acoustic tiles \& insulation } \\
\text { Ceiling height } 9^{\prime} \text {. }\end{array}$ & $\begin{array}{l}\text { Acoustic tiles } \& \text { insulation. } \\
\text { Ceiling height } 9^{\prime} \text {. }\end{array}$ \\
\hline & Floor & $4 "$ concrete slab on gravel. & $4^{\prime \prime}$ concrete slab on gravel. \\
\hline & Glazing & $\begin{array}{l}\text { Mostly on front side of } \\
\text { building, tinted. }\end{array}$ & $\begin{array}{l}\text { Mostly on front side of } \\
\text { building , } 3 / 16^{\prime \prime} \text { charcoal } \\
\text { tinted. }\end{array}$ \\
\hline
\end{tabular}


Table 2 (cont'd). Case Study Building and System Characteristics

\begin{tabular}{|c|c|c|c|}
\hline \multicolumn{2}{|c|}{ Characteristics } & Case I & Case II \\
\hline \multirow[t]{6}{*}{ EQUIPMENT } & Lighting & $\begin{array}{l}\text { 4-lamp fluorescent light } \\
\text { fixtures. Standard lamps and } \\
\text { ballasts. }\end{array}$ & $\begin{array}{l}\text { 4-lamp fluorescent light } \\
\text { fixtures. Standard lamps and } \\
\text { ballasts. }\end{array}$ \\
\hline & HVAC & $\begin{array}{l}4 \text { packaged roof top units which } \\
\text { are also equipped for gas } \\
\text { heating: } 2 \text { four-ton and } 2 \text { six- } \\
\text { ton units. }\end{array}$ & $\begin{array}{l}\text { Unit heater for plating room, } \\
\text { no central plant. } 18 \text { roof top } \\
\text { cooling units with gas furnaces } \\
\text { (mostly } 5-6 \text { tons). }\end{array}$ \\
\hline & DHW & Directly purchased. & $\begin{array}{l}2 \times 4500 \text { watt commercial } \\
\text { tank type, } 120 \text { gal. }\end{array}$ \\
\hline & Process & $\begin{array}{l}\text { Microcomputers \& electronic } \\
\text { testing equipment, small ovens, } \\
\text { laminate-flow units, small hot } \\
\text { plates next to microscopes, } \\
\text { freezer for epoxies, spot } \\
\text { welders, air compressors, and } \\
\text { vacuum pump. }\end{array}$ & $\begin{array}{l}\text { Transformers, laser-plotter, } \\
\text { vacuum port, several mini \& } \\
\text { micro computers, CAD } \\
\text { systems, drilling equipment, } \\
\text { lamination equipment (vacuum } \\
\text { press, hot \& cold presses), } \\
\text { several big ovens, dry film } \\
\text { processing equipment, } \\
\text { exposure testing equipment, } \\
\text { fully equipped plating shop. }\end{array}$ \\
\hline & Kitchen & 1 refrigerator, 1 soda machine. & $\begin{array}{l}2 \text { cold, } 1 \text { hot vending } \\
\text { machines. Refrigerator. } \\
\text { Coffee machine. Hot and cold } \\
\text { water dispenser. }\end{array}$ \\
\hline & $\begin{array}{l}\text { Office } \\
\text { Equipment }\end{array}$ & $\begin{array}{l}8 \text { personal computers (run } \\
\text { overnight), telephone system, } \\
\text { copy machine, fax. }\end{array}$ & $\begin{array}{l}\text { Most of the offices located in } \\
\text { another building. }\end{array}$ \\
\hline
\end{tabular}


Table 2 (cont'd). Case Study Building and System Characteristics

\begin{tabular}{|c|c|c|c|}
\hline \multicolumn{2}{|c|}{ Characteristic } & Case I & Case II \\
\hline \multirow[t]{4}{*}{ SCHEDULES } & Occupancy & $\begin{array}{l}8 \text { a.m. to } 5 \text { p.m., weekdays, } \\
\text { maximum occupancy of } 17 \\
\text { people ( } 80 \% \text { of these are in the } \\
\text { building all the time). } \\
\text { Custodial service } 7 \text { p.m.- } 9 \text { p.m. } \\
\text { two days during the week. }\end{array}$ & $\begin{array}{l}24 \text { hours a day, Sunday } 10 \\
\text { p.m. - Saturday } 5 \text { p.m. } 50 \\
\text { people/shift, } 3 \text { shifts/day. } \\
\text { Custodial services on Sat-Sun }\end{array}$ \\
\hline & Lights & $\begin{array}{l}\text { Manual control, they have } \\
\text { strategy switching on/off. Timer } \\
\text { for outdoor lights. }\end{array}$ & On all the time. \\
\hline & HVAC & $\begin{array}{l}\text { Zone reset thermostats. } \\
\text { Heating } 68^{\circ} \mathrm{F}-72^{\circ} \mathrm{F} \text {, set back to } \\
55^{\circ} \mathrm{F} \text {. } \\
\text { Cooling } 77^{\circ} \mathrm{F} \text {, set up to } 85^{\circ} \mathrm{F} \text {. } \\
\text { Outdoor air dampers partially } \\
\text { open. }\end{array}$ & $\begin{array}{l}\text { Zone reset thermostats. } \\
\text { Heating } 68^{\circ} \mathrm{F} \text {. } \\
\text { Cooling } 72^{\circ} \mathrm{F} \text {. } \\
\text { Outdoor air dampers not used } \\
\text { because of pollution problems. }\end{array}$ \\
\hline & Process & $\begin{array}{l}\text { Microcomputers are on all the } \\
\text { time. Electronic testing } \\
\text { equipment and microscopes } \\
\text { operated during work hours. } \\
\text { Laminar flow device is on all } \\
\text { the time. Spot welders, ovens } \\
\text { are used for short periods. }\end{array}$ & $\begin{array}{l}\text { Most of the process equipment } \\
\text { operated continuously between } \\
\text { Sunday } 10 \text { p.m - Saturday } 5 \\
\text { p.m. }\end{array}$ \\
\hline $\begin{array}{l}\text { ENERGY } \\
\text { PURCHASES }\end{array}$ & & Gas/Electricity/Hot Water & Gas/Electricity \\
\hline
\end{tabular}




\section{ANAL YSIS}

\section{Design of Building and Equipment}

Two different approaches were taken when the two buildings were being designed. The building in Case Study 1 was built speculatively. Equipment installation and most of the interior of the building had been finished before the building was leased. In Case Study 2, however, the building service equipment was designed with input from the user. Table 3 gives the details of the design process for each case, and the following discussion examines the design process in greater detail.

The Case Study 1 building was built as a non-specified (general) leasable building. It was partitioned, and the HVAC equipment was specified to cope with loads of an office-type environment. The developer targeted the building for use as an office or a small-scale manufacturing facility (producing instrumentation, automotive parts, small assemblies, electronics related components, equipment services, etc.). These buildings can be used by a very wide range of users. Some of the other companies occupying the same industrial complex were involved in small-scale industrial activities such as computer mother-board manufacturing, gas pump servicing, electronic-navigation instrument servicing, machine shop manufacturing, electronic chip manufacturing, and printing. The design procedure followed by the owner company, who manages several such industrial parks, was to install standard HVAC equipment without accurate consideration of how the building would be used. The interior and lighting systems were built as the space was leased. If the HVAC equipment was not sufficient for a particular activity, the tenants bought equipment to satisfy their own needs.

The Case Study 2 building was built in 1981 as a non-specified leasable building. The interiors, the lighting equipment, and the HVAC equipment were specified and built by the tenants because their processes required special ventilation and HVAC designs. The experiences of this company provided clues on how a building modified to suit such specialized equipment is transferred from one tenant to the next. This company occupied another building before moving into the existing complex. A another, smaller company working in the same field bought the HVAC and some of the specialized equipment in the old building. A company official described the reselling of the HVAC equipment as a very common practice in that field. 
Table 3. Case Study Buildings and Systems Design Process

\begin{tabular}{|c|c|c|}
\hline Characteristic & Case I & Case II \\
\hline Potential Occupant & $\begin{array}{l}\text { Leasing for office or light } \\
\text { industrial use. }\end{array}$ & $\begin{array}{l}\text { Leasing to whoever is interested } \\
\text { including industrial use. }\end{array}$ \\
\hline Interior Designs & $\begin{array}{l}\text { Partially completed before } \\
\text { leasing. Completed after leasing. }\end{array}$ & Not built before leasing. \\
\hline $\begin{array}{l}\text { Lighting System } \\
\text { Designs }\end{array}$ & $\begin{array}{l}\text { Specified and completed after } \\
\text { leasing. Most of the areas have } \\
1.4 \mathrm{w} / \mathrm{ft}^{2} \text { lighting. Some areas } \\
\text { have } 2 \mathrm{w} / \mathrm{ft}^{2} \text { lighting. }\end{array}$ & $\begin{array}{l}\text { Specified and built after leasing. } \\
\text { Lighting level is }-1.3 \mathrm{w} / \mathrm{ft}^{2} \text {. }\end{array}$ \\
\hline \multirow[t]{2}{*}{ HVAC System Design } & $\begin{array}{l}\text { Sized speculatively, designed and } \\
\text { built before leasing. }\end{array}$ & $\begin{array}{l}\text { The tenant took over the } \\
\text { responsibility of having the HVAC } \\
\text { system designed and built. }\end{array}$ \\
\hline & $\begin{array}{l}\text { Roof top units of standard size } \\
\text { are used (typically } 4-5 \text { tons). } \\
\text { Zones are assigned to these units. } \\
\text { The units are grossly oversized } \\
\text { causing the use of these at part } \\
\text { load all the time. }\end{array}$ & $\begin{array}{l}\text { There has been a genuine attempt } \\
\text { to size the equipment to match } \\
\text { internal load generated. In the } \\
\text { cases where the equipment } \\
\text { manufacturer supplied good } \\
\text { documentation, the HVAC } \\
\text { equipment was sized correctly. In } \\
\text { some areas there is oversizing. }\end{array}$ \\
\hline $\begin{array}{l}\text { Related to } \\
\text { Comfort }\end{array}$ & $\begin{array}{l}\text { The zones served by the same } \\
\text { unit are used for different } \\
\text { purposes, some zones are over } \\
\text { cooled. }\end{array}$ & $\begin{array}{l}\text { The zones served by the same unit } \\
\text { are used for different purposes, } \\
\text { some zones are over-cooled. One } \\
\text { thermostat not in the proper zone. }\end{array}$ \\
\hline $\begin{array}{l}\text { Ownership of HVAC } \\
\text { Equipment }\end{array}$ & Building owner & Building tenant \\
\hline $\begin{array}{l}\text { Conditions on Lease } \\
\text { Termination }\end{array}$ & There are no complications. & $\begin{array}{l}\text { The tenant has to market and sell } \\
\text { the customized HVAC system to } \\
\text { the next tenant. }\end{array}$ \\
\hline
\end{tabular}


In both case studies, lighting systems were built after the buildings were leased. Hence, they matched the needs for the activities. Also, visits to the buildings indicated that the designers had taken advantage of some of the energy-efficient technologies in designing the lighting systems.

A review of these case studies suggests the following overall process for the design of industrial buildings and equipment. The developers of industrial parks decide, based on current market conditions, either to subdivide the building or to market it as a whole. If they subdivide, they typically have the HVAC system designed and installed. In such cases, they size the equipment for office-type use. On the other hand, if they decide to lease the building as a whole, they defer the design and installation of the interior lighting and the HVAC equipment until after the space is leased. At that point, they negotiate the lighting and HVAC systems costs together with the rent: either the owner has these systems built or the tenant assumes the responsibility and the ownership of the lighting and HVAC equipment.

A fundamental barrier impedes improvements in energy efficiency in building services. Neither the owner nor the user thinks that much would be saved by implementing energy-saving measures or by better design. The owners do not consider energy efficiency since they do not pay the energy bills. For tenants, energy costs are a small fraction of the total operational costs of such businesses. As a result, the building, the lighting system, and the HVAC system are built without considering energy efficiency. Facility operators of the case-study buildings were much more sensitive to issues like environmental regulations and to how changes would affect their operations in the future. In interviews, they stated they were willing to invest significantly more funding to ensure that they would be able to adjust to future regulatory requirements.

In the cases where the HVAC equipment was built for standard office use, we found that the equipment was oversized. Typically, cooling units of standard size were used, and zones were connected to a unit based on floor area with minimal attention paid to the function and internal loads of the zone. Where the HVAC system was custom-built, we observed some significant design flaws resulting in either energy inefficiencies or substandard comfort conditions. These flaws included:

(1) Using an HVAC unit of standard size and connecting zones of different functions to the same unit. If two zones are connected to the same unit and one requires more cooling than the other, one of the zones will not meet specified comfort criteria. This problem arises because typical systems do not include zone reheat equipment. 
(2) Placing the thermostat of a certain zone in another closeby zone, resulting in inadequate control of the HVAC equipment.

(3) Not being able to size equipment for cooling zones with certair. processes. Manufacturers' catalogues and drawings are usually not adequate for estimating process heat generation. HVAC engineers are not well equipped to tackle the air-conditioning problems of buildings housing industrial processes. Attempts to customize the HVAC equipment to the process involved have occurred, but generally the equipment was oversized. (For one zone, in the Case Study 2 building, there existed very detailed manufacturer's data for the process equipment including the heat generation, and the HVAC equipment is sized very accurately to meet the zone load. The process equipment happened to be used full load all the time.) Another related issue is that the rated performance of a process may be substantially different than its actual heat generation. This means that even if there exists proper manufacturer's data on the heat generation, an analysis of the operating hours and part load heat generation is necessary to estimate the contribution of the particular process to the zone load.

\section{Energy-Use Patterns and Characteristics}

To compare the energy-use patterns of these two buildings, we examined the details of the processes housed in them and simulated the energy use of the buildings using DOE-2. We compared the simulation results with the utility billing data. Although utility bills did not show energy use by end use, they were useful for calibrating our models. A detailed analysis of all of the processes was essential so that we could accurately estimate internal heat gains from process loads.

Table 4 shows the utility bill data for both facilities. ${ }^{2}$ Gas consumption (mainly for space heating) was low in both buildings because these facilities are located in a mild climate. In Case Study 2 , the heating requirement was even lower because of the high internal heat gains from the processes equipment. For Case Study 1, the pattern of monthly electricity use reflected the climatic seasonality of air-conditioning use. For Case Study 2 the monthly electricity-use pattern was more affected by the seasonality of production than air-conditioning requirements. The

2 October and November electricity data for Case Study 2 were missing; we imputed data for these periods by i.1terpolation. 
Table 4. Monthly Electricity and Gas Consumption Data for Case Study Facilities ${ }^{(1)}$

\begin{tabular}{|c|c|c|c|c|c|c|c|c|c|c|c|c|}
\hline & \multicolumn{6}{|c|}{$\begin{array}{c}\text { CASE I (Oct 89-Sept 90) } \\
4620 \mathrm{ft}^{2}\end{array}$} & \multicolumn{6}{|c|}{$\begin{array}{c}\text { CASE U (Feb 89-Jan 90) } \\
25990 \mathrm{ft}^{2}\end{array}$} \\
\hline & \multicolumn{2}{|c|}{ ELEC } & \multicolumn{2}{|c|}{$\begin{array}{c}\text { ELEC } \\
\text { DEMAND }\end{array}$} & \multicolumn{2}{|c|}{ GAS } & \multicolumn{2}{|c|}{ ELEC } & \multicolumn{2}{|c|}{$\begin{array}{c}\text { ELEC } \\
\text { DEMAND }\end{array}$} & \multicolumn{2}{|c|}{ GAS } \\
\hline MTH & $\mathrm{kWh}$ & $\mathrm{kWh} / \mathrm{t}^{2}$ & $\mathrm{~kW}$ & $W ! t^{2}$ & MBtu & $\mathrm{kBtu} / \mathrm{f}^{2}$ & $\mathrm{kWh}$ & $k W h / t^{2}$ & $k W$ & $W / t^{2}$ & $M B t u^{2}$ & $\mathrm{kBtu} / \mathrm{ft}^{2}$ \\
\hline Jan & 4080 & .88 & 15 & 3 & 23.9 & 5 & 194,700 & 7.49 & 423 & 16 & 33.0 & 1 \\
\hline Feb & 3840 & .83 & 15 & 3 & 20.8 & 5 & 191,400 & 7.36 & 357 & 14 & 85.4 & 3 \\
\hline Mar & $4200^{\circ}$ & .90 & N/A & & 20.8 & 5 & 154,200 & 5.93 & 357 & 14 & 14.0 & 1 \\
\hline Apr & 4640 & 1.00 & 26 & 6 & 6.7 & 2 & 189,600 & 7.30 & 360 & 14 & 0 & 0 \\
\hline May & 4080 & .88 & 26 & 6 & 3.4 & 1 & 199,500 & 7.67 & 369 & 14 & 0 & 0 \\
\hline Jun & 5840 & 1.26 & 33 & 7 & 2.3 & 1 & 177,000 & 6.81 & 387 & 15 & 0 & 0 \\
\hline Jul & 6720 & 1.45 & 31 & 7 & 1.1 & 0 & 179,100 & 6.89 & 408 & 16 & 0 & 0 \\
\hline Aug & 6640 & 1.44 & 30 & 7 & 1.0 & 0 & 189,300 & 7.09 & 414 & 16 & 0 & 0 \\
\hline Sep & 6240 & 1.35 & 30 & 7 & 1.0 & 0 & 180,000 & 6.93 & 414 & 16 & 0 & 0 \\
\hline Oct & 4240 & .91 & 22 & 5 & 1.5 & 0 & $\begin{array}{c}180,000^{(2)} \\
72,900 \\
(12 \text { days })\end{array}$ & 6.93 & 414 & 16 & 0 & 0 \\
\hline Nor & 4000 & .87 & 16 & 4 & 3.0 & 1 & $180,000^{(2)}$ & 6.93 & $\mathrm{n} / \mathrm{a}$ & - & 3.2 & 0 \\
\hline Dec & 3520 & .76 & 15 & 3 & 10.1 & 2 & 183,000 & 7.04 & 417 & 16 & 33.4 & 1 \\
\hline Total & 58,040 & 12.56 & 33 & 7 & 95.6 & 21 & $22,197,800$ & 84.56 & 423 & 16 & 1690 & 6 \\
\hline
\end{tabular}

"Source: Utility bills.

${ }^{(2)}$ Data missing. Interpolated. 
production level in Case Study 2 was not always predictable, and there were times when the company had more orders than usual.

For data on processes, we relied on audits and site measurements or published materials. For a majority of the heat-generating equipment (such as ovens and hot presses), we performed surface temperature measurements and collected information on the usage schedule of the process equipment to estimate the internal heat gains in the buildings.

Having determined the contribution of the process equipment to the internal heat gains and the sizes of the HVAC equipment as accurately as possible, we simulated building energy use with DOE-2. Since we did not have detailed measured data on process loads, our calibrations of DOE-2 simulations were fairly limited; we assumed that the energy used over and above the levels calculated by DOE-2 were for the processes. Table 5 shows the energy-use characteristics for the buildings studied. Table 6 compares the electricity-use intensities for the two cases with the results obtained by the analysis of the PG\&E Energy Utilization Audit (PG\&E/EUA) data (Akbari et al.1991) and with typical energy-use intensities for California office, retail, and warehouse buildings (Akbari et al. 1989).

Table 6 shows that electricity use for both lighting and HVAC for both case-study buildings are very close to those intensities found in offices (perhaps also retail). The lighting electricity use in Case Study 1 was low because a large percentage of the floor space benefited from daylighting, and some sections of the building were not lighted most of the time. Also, the characteristics of the equipment in Case Study 1 were about the same als offices with almost the same characteristic internal heat gains. Similarities between the case-study buildings and office buildings suggest that a considerable amount of industrial floorspace could benefit from the same conservation measures that are applicable to office buildings. We will discuss these measures and their impact on energy use and peak power in the following sections.

As indicated earlier, gas in these facilities vas used mainly for space heating. The annual gas consumption for Case Study 1 and Case Study 2 was $22 \mathrm{kBtu} / \mathrm{ft}^{2}$ and $7 \mathrm{kBtu} / \mathrm{ft}^{2}$, respectively. The corresponding average gas-use intensities estimated from the PG\&E/EUA are $22 \mathrm{kBtu} / \mathrm{ft}^{2}$ for instruments and $23 \mathrm{kBtu} / \mathrm{ft}^{2}$ for electronics. The gas-use intensity in Case Study 2 , because of high internal gains from process loads, was low. 
Table 5. Simulated Annual Electricity and Gas Consumptioı and Comparison with Metered Annual Energy Data. Note that the difference between the simulated energy use and the utility data, assumed in this analysis as the process load, is fairly small in Case Study 1 and very large in Case Study 2. This observation is confirmed by the process loads in these facilities.

\begin{tabular}{|c|c|c|c|c|}
\hline & \multicolumn{2}{|c|}{ Case I } & \multicolumn{2}{|c|}{ Case II } \\
\hline & $\begin{array}{c}\text { ELEC } \\
(\mathrm{kWh} / \mathrm{yr})\end{array}$ & $\begin{array}{c}\text { GAS } \\
\text { (kBtu/yr) }\end{array}$ & $\begin{array}{c}\text { ELEC } \\
(\mathrm{kWh} / \mathrm{yr})\end{array}$ & $\begin{array}{c}\text { GAS } \\
(\mathrm{kBtu} / \mathrm{yr}) \\
\end{array}$ \\
\hline $\begin{array}{l}\text { HVAC }^{(\mathbf{l})} \\
\quad \text { Cooling }\end{array}$ & 4,655 & N/A & 307,962 & N/A \\
\hline Heating & N/A & 64,317 & N/A & 140,078 \\
\hline Fan & 33,200 & N/A & 148,939 & N/A \\
\hline Total & 37,855 & N/A & 281,747 & N/A \\
\hline Lighting ${ }^{(1)}$ & 7,642 & N/A & 281,747 & N/A \\
\hline Total Services $^{(1)}$ & 45,497 & 64,317 & 738,244 & 140,078 \\
\hline Total Building Meter ${ }^{(2)}$ & 58,040 & 95,600 & $2,197,800$ & 169,000 \\
\hline
\end{tabular}

${ }^{(1)}$ Simulated values, weather data for San Jose was used.

${ }^{(2)}$ Measured data obtained from utility bills (including processes), missing months are interpolated.

N/A: Not applicable. 
Table 6. Comparison of Electricity Use Intensities of the Case-Study Buildings with PG\&E Industrial Data. The intensities for office, retail and warehouse buildings are typical ranges report in Akbari et al. 1989.

\begin{tabular}{|lccc|}
\hline & $\begin{array}{c}\text { Lighting } \\
\mathrm{kW} / \mathrm{ft}^{2}\end{array}$ & $\begin{array}{r}\mathrm{HVAC} \\
\mathrm{kW} / \mathrm{ft}^{2}\end{array}$ & $\begin{array}{c}\text { Equipment } \\
\mathrm{kW} / \mathrm{ft}^{2}\end{array}$ \\
\hline Instruments & & & \\
$\quad$ Case Study 1 & 1.7 & 8.2 & 2.7 \\
PG\&E/EUA & 7.1 & 8.3 & 8.4 \\
\hline Electronics & & & \\
Case Study 2 & 10.8 & 17.6 & 56.1 \\
PG\&E/EUA & 10.0 & 17.3 & 27.1 \\
\hline \hline Office & $5-8$ & $5-9$ & $1-2.5$ \\
Retail & $5-8$ & $3-5$ & $1-2$ \\
Warehouse & $3-4$ & $1-2$ & $.25-.75$ \\
\hline
\end{tabular}

\section{Energy Conservation Potentials}

Having simulated the existing energy-use patterns, we studied the effectiveness of some energy conservation measures that typically apply to commercial buildings. The findings are summarized in Table 7. The buildings already had insulation above the acoustic ceiling tiles; therefore, roof insulation was not included in our analysis. The envelope measures resulted in little savings, due to the mild climate of the San Jose-Santa Clara area. These measures saved some heating energy, but this gain typically did not compensate for the increase in airconditioning electricity use.

We found the conservation measures involving the HVAC and the lighting systems to be more effective than the envelope measures. We investigated the effects of using highperformance compressors, economizers, fan scheduling, and adjustable speed drives (ASD) on the fan motors. We also tried to size the HVAC equipment to match the actual loads in the building. We investigated how a central HVAC system would perform under the circumstances. Finally, we applied more efficient lighting equipment. 
Table 7. Impacts of Conservation Measures on HVAC Energy Use

\begin{tabular}{|c|c|c|c|c|c|c|}
\hline & \multicolumn{3}{|c|}{ Case I } & \multicolumn{3}{|c|}{ Case II } \\
\hline & $\begin{array}{l}\text { Heating } \\
\text { Gas } \\
(\mathrm{kBtu} / \mathrm{yr})\end{array}$ & $\begin{array}{l}\text { Cooling } \\
\text { Elec. } \\
(\mathrm{kWh} / \mathrm{yr})\end{array}$ & $\begin{array}{l}\text { Fan Elec. } \\
\text { (kWh/yr) }\end{array}$ & $\begin{array}{l}\text { Heating } \\
\text { Gas } \\
(\mathrm{kBtu} / \mathrm{yr}) \\
\end{array}$ & $\begin{array}{l}\text { Cooling } \\
\text { Elec. } \\
(\mathrm{kWh}) \\
\end{array}$ & $\begin{array}{c}\text { Fan } \\
\text { Elec. } \\
(\mathrm{kWh}) \\
\end{array}$ \\
\hline BASE CASE ${ }^{(1)}$ & 64,317 & 4,655 & 33,200 & 140,078 & 307,562 & 148,935 \\
\hline Savings (in percentage) & \% Savings & \% Savings & $\%$ Savings & $\%$ Savings & $\%$ Savings & $\%$ Savings \\
\hline \multicolumn{7}{|l|}{$\begin{array}{l}\text { Envelope } \\
\qquad \text { Wall Insulation } \\
\qquad Q \rightarrow R 5\end{array}$} \\
\hline $\mathrm{R} \theta \rightarrow \mathrm{R} 11$ & 28 & -14 & 0 & 48 & -4 & 0 \\
\hline $\begin{array}{l}\text { Wall Color } \\
\qquad \text { Normal } \rightarrow \text { Lighi }\end{array}$ & -6 & 7 & 0 & -9 & 1 & 0 \\
\hline $\begin{array}{l}\text { Roof Color } \\
\qquad \text { Normal } \rightarrow \text { Light }\end{array}$ & -3 & 2 & 0 & -2 & 0 & 0 \\
\hline \multicolumn{7}{|l|}{$\begin{array}{l}\text { HVAC System } \\
\text { Roof Top Unit } \\
\text { COP } 2.5 \rightarrow 2.8\end{array}$} \\
\hline COP $2.5 \rightarrow 3.0$ & 0 & 16 & 0 & 0 & 16 & 0 \\
\hline Economizer & 0 & 9 & 0 & 0 & 57 & 0 \\
\hline Fan Schedule & -13 & 8 & 74 & N/A & N/A & N/A \\
\hline ASD on Fans & 0 & 5 & 88 & 0 & 6 & 62 \\
\hline $\begin{array}{l}\text { Equipment Sized to the } \\
\text { Existing Load } \\
\text { (3) }\end{array}$ & -31 & 17 & 75 & -5 & 10 & 14 \\
\hline $\begin{array}{l}\text { Central System } \\
\text { Cooling Tower }\end{array}$ & -61 & $8^{(2)}$ & 88 & -345 & $34^{(2)}$ & -37 \\
\hline Air & -61 & $8^{(2)}$ & 88 & -345 & $39^{(2)}$ & -37 \\
\hline $\begin{array}{l}\text { Lighting } \\
\text { T8 Lamps with } \\
\text { Electronic Ballasts }\end{array}$ & -10 & 9 & 0 & -39 & 3 & 0 \\
\hline \multicolumn{7}{|c|}{$\begin{array}{l}\text { (1) Base Case: } \\
\text { Wall Insulation: R } \emptyset \text {, Wall Color: Normal, Roof Color: Normal, Roof-top unit with compressor COP of } 2.5 \text {, } \\
\text { No Economizer, No Fan Schcdule, No ASDs, Standard } 4 \mathrm{ft} \text {. fluorescent lamps and fixtures } \\
\text { (2) Figure includes zone reheat electricity. } \\
\text { (3) No provisions for future expansion. } \\
\text { N/A Not applicable. }\end{array}$} \\
\hline
\end{tabular}


The use of economizers has ? iarge impact on compressor energy use. However, econornizers are not always feasible because of the possibility of recirculating undesirable gases from nearby exhausts. In Case Study 2, for example, the building operators had to keep most of the dampers closed to prohibit the exhaust gases from the plating shop being recirculated in the building. This issue should be considered during the design stage so that exhausts and intakes can be separated by a safe distance based on the air movement studies around the building.

Supply fan scheduling also has a large impact on the fan motor energy use if the facility is used one or two shifts a day. For facilities operating three shifts, fan scheduling clearly does not yield significant energy savings.

Adjustable speed drives on the fan motors are an effective means of closely matching the energy used by the motors to the fan loads. Use of ASD also results in a small reduction in the compressor energy use because less heat is added to the system by the fan motors. As mentioned, in growth industries (like electronics and instruments), HVAC systems are generally oversized to accommodate the rapid growth of the companies. This oversizing may result in HVAC equipment being operated at part-load conditions. Adjustable speed drives facilitate energy conservation while guaranteeing the future availability of HVAC capacity.

Having observed that the HVAC equipment was usually oversized, we sized the equipment to meet the actual loads. The results showed savings both in fan and compressor electricity use. As mentioned before, there had been an attempt in Case Study 2 to size the HVAC equipment to match the internal loads. In Case Study 1, on the other hand, the oversized equipment was installed speculatively. In any case, it is difficult to argue for the proper sizing of equipment because the tenants of these buildings are very dynamic; businesses sometimes grow very fast, and in a short time the facility may require much greater HVAC services.

One way of improving HVAC energy performances is the use of central cooling systems. Central HVAC systems usually have better cooling performance at the expense of additional ventilation and air circulation costs. In Case Study 1, using a central HVAC system could reduce electricity consumption considerably, but the savings might not justify the extra capital investment. In Case Study 2 although compressor energy was reduced, fan energy use increased because of duct losses. Overall, for Case Study 2, a central system did not look particularly attractive.

Delamping was not necessary in these buildings since the lighting levels were already low. Multi-switching and occupancy sensors are already being used when suitable. An applicable 
conservation measure is the use of more efficient lighting components. In Case Study 1, the decrease in compressor energy use resulting from efficient lighting components was offset by an increase in heating requirements. In Case Study 2, the increase in heating greatly outweighted the compressor savings.

The combined impact of several of the measures given in Table 7 is shown in Figure 3. The measures included in this figure are fan scheduling, economizers, efficient compressors, and efficient lighting components for Case Study 1; ASDs, economizers, efficient compressors, and efficient lighting components for Case Study 2. Figure 3 shows a lower limit to the technical savings potential for conservation for the two facilities. It is clear that the savings potential in electricity use in both cases is higher than $50 \%$. Note that we have not addressed potentials for increasing energy efficiency in process loads. It is harder to quantify the saving potential in gas use because these buildings are located in a mild climate, and heating require:nents are very low.

We have not explicitly addressed the cost of conserved energy and power in the facilities we studied. Since the non-process energy-saving measures in these facilities are very much comparable to those generally recommended for office buildings, we expect corresponding conservation measures to have similar costs. Many studies of commercial buildings, particularly offices, have concluded that typically about one-third of the energy in buildings can be saved by conservation measures with less than two years payback. 
Figure 3.

Technical Potential for Conservation in Energy Used for Building Services

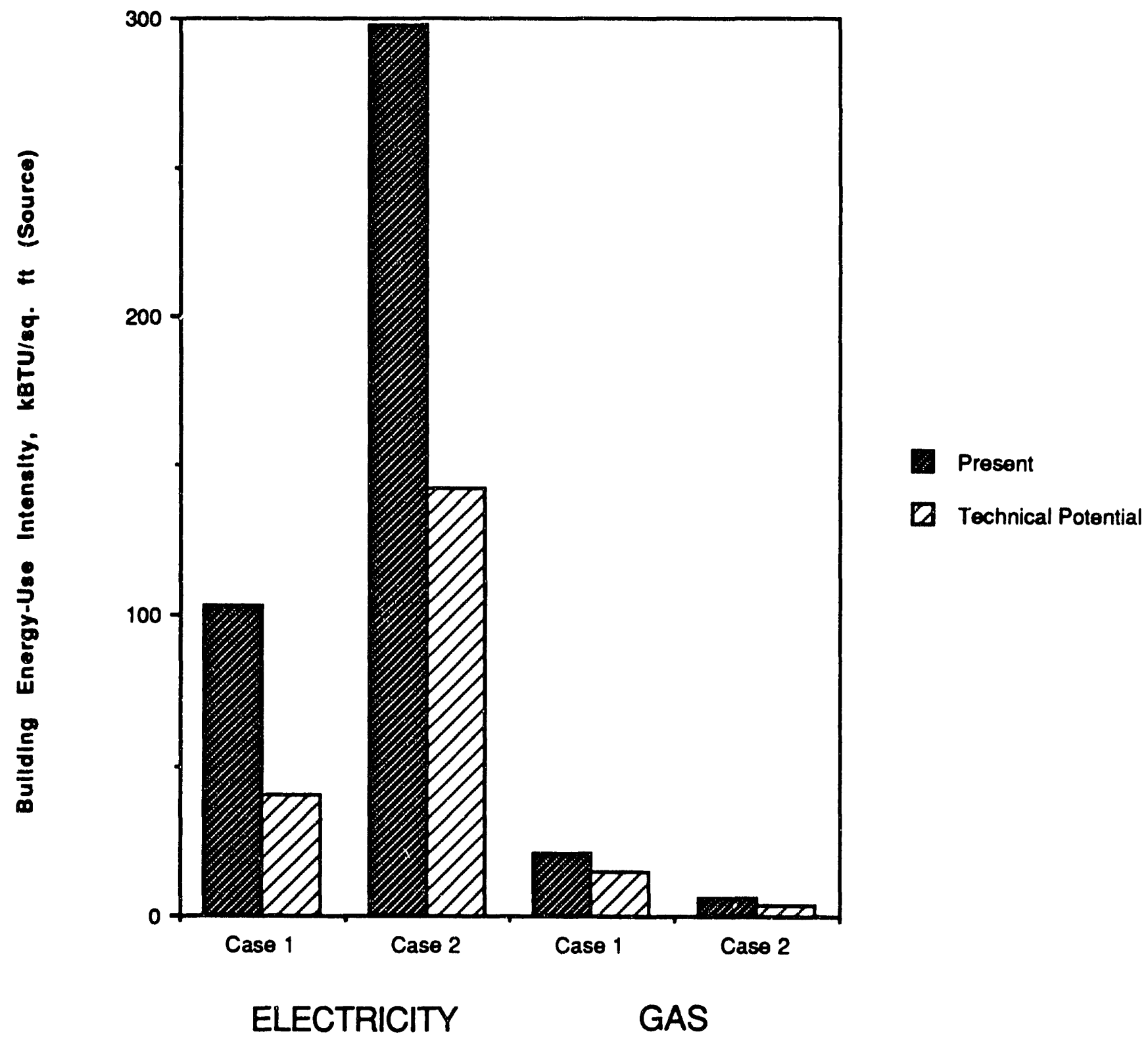




\section{Load-Shaping Potentials}

Although each industrial facility and its operation is unique, there are, nonetheless, significant similarities in electric load profiles and in the potential for implementing loadshaping measures. Akbari et al. (1986) have discussed in detail the process and non-process loads in a few California industries and have identified applicable load-shaping measures to both types of loads. Those specific load-shaping measures recommended for the non-process loads in computer and electronics industries include efficiency improvement in lighting and airconditioning equipment, shifting of energy-intensive operations (such as charging electric forklift trucks) to off-peak periods, and the application of thermal storage for process and HVAC cooling. In this exploratory study, we only address the potentials of these load-shaping technologies as they apply to the building services of the two case studies.

Conservation measures discussed in the previous section would usually reduce the peak electricity demand. Table 8 shows how these measures affect the peak electricity demand. In Case Study 1, since the HVAC system is oversized, the use of ASDs and proper sizing of HVAC equipment would result in substantial peak reductions. In Case Study 2, where the HVAC equipment was designed to match the loads, the reductions caused by ASDs and proper sizing were not as high. Fan scheduling was not effective for peak reduction because the benefits of this measure usually occured at off-peak hours. The use of efficient compressors and efficient lighting equipment, however, would result in peak reduction.

Economizers and ASDs do not usually reduce on-peak demand. (If fan and compressor motors are significantly oversized, ASDs will save on-peak demand.) Since HVAC systems are usually sized for design-day conditions, the peak reduction would not be significant on very warm days, but there are savings for days with less than design-day loads. Better control of lighting is also an important measure for on-peak demand reduction: daylighting techniques can and are being employed to some extent in the suitable sections of the case-study buildings. Also, motion sensors can be used in spaces that are not occupied continually.

In Case Study 2, chillers were used to provide process cooling and package systems were used for environmental cooling. A thermal energy storage (TES) system can shift both process and environmental cooling loads to off-peak hours and, thereby, save significant peak demand charges. 
Table 8. Impact of Conservation Measures on Peak Electricity Demand

\begin{tabular}{|c|c|c|}
\hline & Case I & Case II \\
\hline & Peak Use (kW) & Peak Use (kW) \\
\hline BASE CASE ${ }^{(1)}$ & 46 & 523 \\
\hline Peak Reduction (in percentage) & \% Reduction & \% Reduction \\
\hline \multirow{2}{*}{$\begin{array}{l}\text { Envelope } \\
\qquad \begin{array}{r}\text { Wall Insulation } \\
R \theta \rightarrow R 5 \\
R Q \rightarrow R 11\end{array}\end{array}$} & 7 & 4 \\
\hline & 4 & 4 \\
\hline $\begin{array}{l}\text { Wall Color } \\
\quad \text { Normal } \rightarrow \text { Light }\end{array}$ & 4 & 2 \\
\hline $\begin{array}{c}\text { Roof Color } \\
\text { Normal } \rightarrow \text { Light } \\
\end{array}$ & 0 & 2 \\
\hline \multirow{6}{*}{$\begin{array}{l}\text { System } \\
\text { Roof Top Unit } \\
\text { COP } 2.5 \rightarrow 2.8 \\
\text { COP } 2.5 \rightarrow 3.0 \\
\text { Economizer } \\
\text { Fan Schedule } \\
\text { ASD on Fans } \\
\text { Equipment Sized to the Existing } \\
\text { Load }\end{array}$} & 8 & 7 \\
\hline & 13 & 11 \\
\hline & 0 & -3 \\
\hline & 2 & N/A \\
\hline & 39 & 7 \\
\hline & 39 & 10 \\
\hline $\begin{array}{l}\text { Central System } \\
\text { Cooling Tower }\end{array}$ & 41 & 7 \\
\hline Air & 39 & -2 \\
\hline $\begin{array}{l}\text { Lighting } \\
\quad \text { T8 Lamps with Electronic Ballasts }\end{array}$ & 9 & 11 \\
\hline \multicolumn{3}{|c|}{$\begin{array}{l}\text { (1) Base Case: } \\
\text { Wall Insulation: R } 0 \text {, Wall Color: Normal, Roof Color: Normal, Roof-top unit with } \\
\text { compressor COP of } 2.5 \text {, No Economizer, No Fan Schedule, No ASDs, Standard } 4 \mathrm{ft} \text {. } \\
\text { fluorescent lamps and fixtures } \\
\text { (2) No provisions for future expansion. } \\
\text { N/A Not applicable. }\end{array}$} \\
\hline
\end{tabular}




\section{CONCLUSION}

This is the second of two reports resulting from an exploratory project. In the first report (Akbari et al. 1991), we performed an extensive survey of the existing publicly available data and characterized and compared the building energy uses in a variety of California industries. In this second report, we documented the results of our analysis for two case studies in California. Based on the information obtained for the selected case studies, we discussed design considerations for industrial buildings, characterized their energy use, and reviewed their conservation and load-shaping potentials.

The PG\&E Energy Utilization Audit for northern and central California showed that the energy use in the building services of some growth industries is significant. There is a need for further characterization of these energy uses and patterns. This study has enabled us to understand the energy-use patterns in some industrial facilities in the PG\&E service area. Studies of this nature need to be extended to cover other industries as well as to cover other important and populated regions of the state. Such efforts will determine the total energy use, conservation, and load-shaping potentials for building services by industry.

The selected case studies have provided valuable information on two growing industries in California. One major finding of this study is that the lighting and HVAC energy-use characteristics of high-tech industries and their conservation potentials are very much comparable to those of office buildings. By simulating the impact of conservation measures commonly recommended for office buildings in our two case studies, we estimated that more than $50 \%$ of electricity and gas use for the building services could be saved. Case studies in other regions and for other important industries can be useful tools to assist us in better understanding the energy-use patterns and the impact of conservation and load-shaping measures on the industrial loads.

What needs to be done? This study has been exploratory in nature and many of its conclusions should be considered preliminary. However, the study has suggested that energy use, energy efficiency, and the load-shaping opportunities in this sector are important and should receive due attention by both the California utilities and researchers. Although we do not intend to scope a full-scale research project is this area, we recommend the following research topics:

- Generate a data base for industrial building energy services addressing both base energy use and conservation potentials. This data base would allow us to identify industries with greater load-shaping and conservation potentials. 
- Generate a list of data base parameters across industry categories to assist in the assessment of benefits and risks of adoption of integrated energy systems (co-generation or selfgeneration). This will greatly benefit forecasting models of energy demand and mix. The data base should highlight those industries in California that are likely to adopt advanced electrotechnologies.

- Identify future research activities needed to examine the anticipated impact of greater use of electrotechnologies and new advanced gas technologies on the building service energy requirements in selected growth industries. Develop a research agenda for the California utilities in the area of industrial building services. This research agenda should also address the impact of a shift by industry to on-site integrated energy systems.

- Organize a workshop among California utilities, researchers, and legislators, to discuss industrial energy efficiency. 


\section{REFERENCES}

Akbari, H., Borgers, B., Gadgil, A., and Sezgen, O. (1991) "Analysis of energy use in building services of the industrial sector in Califormia: A literature review and a preliminary characterization," Lawrence Berkeley Laboratory Report LBL-29749.

Akbari, H., Eto, J., Turiel, I., and Heinemeier, K., Lebot B., Nordman B., and Rainer L. (1989) "Integrated estimation of commercial sector end-use load shapes and energy use intensities," Lawrence Berkeley Laboratory Report LBL-27512.

Akbari, H. and Gadgil, A. (1989) Workshop Proceedings of the Industrial Building Energy Use, Lawrence Berkeley Laboratory Report LBL-27658.

Akbari, H., Almeida, A., Connell, D., Harris, J., and Warren, M. (1986). "Assessment of Energy Management Systems for Monitoring Load-Shaping Measures in Industry," Lawrence Berkeley Laboratory Report LBL-20821, June 1986.

ANCO 1986. "Industrial Load-Shaping Program for the Computing Equipment and Electronics Industries," a Report Prepared by ANCO Engineers Inc. for PG\&E, April 1986.

BAH 1986. Industrial Sector Market Study Report to Pacific Gas and Electric (PG\&E), Booz, Allen and Hamilton Inc., Economics and Forecasting Department, February 26, 1986.

Bodine, Frank J. and Vitullo, Marshall 1980. "Industrial Energy Use Data Book," Report Number ORAU-160, Oak Ridge Associated Universities, Oak Ridge, Tennessee 37830.

Brown, Harry L., Hamel, Bernard B., and Hedman, Bruce A. 1985. Energy Analysis of 108 Industrial Processes, Fairmont Press, Prentice-Hall, P.O. Box 500, Englewood Cliffs, NJ 07632.

Chem Systems 1986. "Industrial Load-Shaping Program: the Plastics Industry," a Report Prepared by Chem Systems Inc. for PG\&E, February 1986.

Chiogioji, Melvin H. 1979. Industrial Energy Conservation, Marcel Dekker Inc., 270 Madison Avenue, New York, N.Y. 10016.

EADC 1987. (Perrotti, G.M., Johnson, J.H., and Kirsh, F.W.), "Energy Conserved and Cost Saved by Small and Medium size Manufacturers," Report for program period 1984-85. Published for DOE by University City Science Center - Center for Energy Management and Industrial Technology January 1987, Philadelphia PA. Phone (215) 387-2255.

ERC 1983. Energy and Resources Consultants Inc., "A Characterization of Energy Use in Selected California Industries," Report submitted to California Energy Commission, April 
1983. (ERC, P.O. Drawer 0, Boulder CO 80306. Phone (303) 449-5515).

Fazzolare, Rocco A. and Smith, Craig B., Editors, 1981. Beyond the Energy Crisis, Proceedings of the Third International Conference on Energy Use Management, Berlin (West), October 26-30, 1981, Pergamon Press Inc., Maxwell House, Fairview Park, Elmsford, New York 10523.

HBC 1987. Hagler Bailly and Company, "Industrial Buildings Energy Use," HBC reference number 87-3025. Prepared for DOE Office of Buildings and Community Systems, Released March 31, 1987.

Hu, David S. 1983. Handbook of Industrial Energy Conservation, Van Nostrand Reinhold Company Inc., 135 West 50th Street, New York,

IETEC, 1984. "Industrial Energy Conservation Technology," Proceedings of the 1984 Conference and Exhibition, April 15-18, 1984, Texas Economic Development Commission and Public Utility Commission of Texas, Austin, Texas.

IEUDB 1980. Oak Ridge Associated Universities "Industrial Energy Use Data Book," Report No. ORAU-160, (1980).

Meckler, Milton, Editor, 1984. Retrofitting of Commercial, Institutional, and Industrial Buildings for Energy Conservation, Van Nostrand Reinhold Company Inc., 135 West 50th Street, New York, N.Y. 10020.

Miller, Craig and Weaver Christopher, 1982. "Aggregation Scheme, Statistical Data, and Preliminary End-Use Characterizations for California Manufacturing Industries," a Report to the California Energy Commission by Energy and Resource Consultants Inc., P.O. Drawer O, Boulder, CO 80306.

NBECS 1982. WESTAT,"Nonresidential Buildings Energy Consumption Survey," Report DOE/EIA-0318/1 to Department of Energy, (1982).

PG\&E 1985. Industrial Load-Shaping Project, draft, Energy Services Department, Pacific Gas and Electric, October, 1985.

Reay, David A. 1979. Industrial Energy Conservation, Second Edition, Pergamon Press Inc., Maxwell House, Fairview Park, Elmsford, New York 10523.

Smith, Craig B., Editor, 1978. Efficient Electricity Use, Second Edition, Pergamon Press Inc., Maxwell House, Fairview Park, Elmsford, New York 10523. 

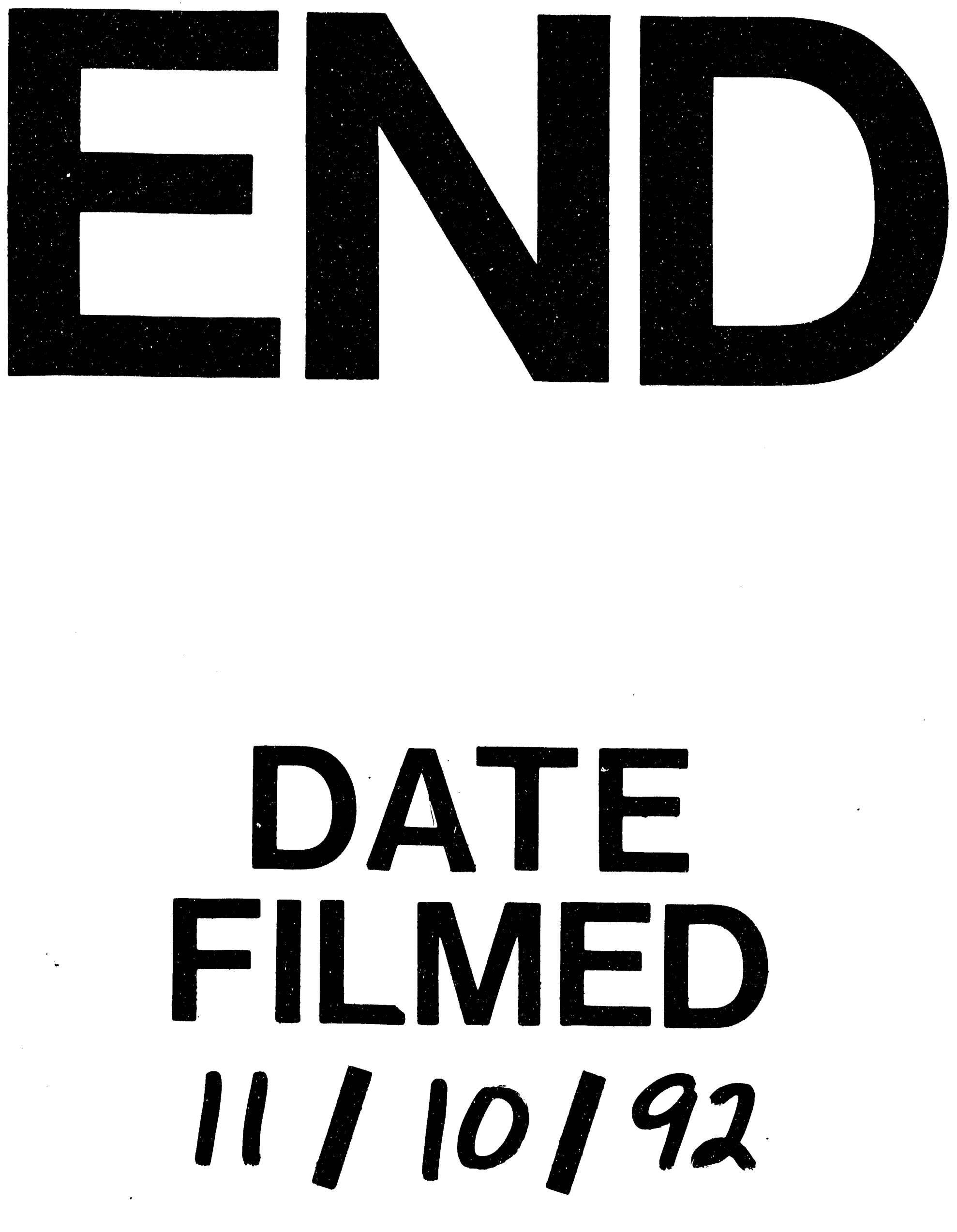

1 
